\title{
PENINGKATAN HASIL BELAJAR SISWA KELAS VI SDN 1 NYALINDUNG KECAMATAN CIPATAT MELALUI MEDIA PEMBELAJARAN PADA MATA PELAJARAN BAHASA INDONESIA TAHUN AJARAN 2012-2013
}

\author{
1) Resmini \\ ${ }^{1}$ Guru SDN 1 Nyalindung Cipatat Kabupaten Bandung Barat \\ Email: ekamaulana889@yahoo.com, resmini@yahoo.com
}

\begin{abstract}
s
This study aims to improve the ability of students in learning Indonesian. The study conducted in Class VI SDN 1 Nyalindung District Cipatat West Bandung district on October 2, 2012 until October 22, 2012. Learning Model through the medium of learning. It is expected to use the model of the approach and direction of research will increase student learning outcomes and can apply and enrich vocabulary Indonesian well and correctly. The successful implementation of these improvements, the learning process, is planned, observed, and evaluated the results in the two study cycles each class 3 meetings. From the results of the implementation study classes in two cycles can be concluded that the model learning through Media Learning can improve learning outcomes and can apply the vocabulary properly in a sentence coherently. It can see the results of the evaluation of the first cycle, the average value achieved by students is 64.75 percent increase to 72.00 .Kemudian completeness of sixth-grade students increased from $54 \%$ increased to $64.75 \%$ in the first cycle, also on the second cycle increased to $72 \%$. The learners are satisfied and motivated to apply it in accordance with time provided.
\end{abstract}

Keywords: The mindset of language, learning approach through the medium of learning

\section{A. PENDAHULUAN}

Pendidikan konvensional memiliki paradigma bahwa guru adalah satusatunya sumber belajar, sehingga dianggap orang yang paling memiliki pengetahuan. Paradigma itu kemudian bergeser menjadi guru lebih dahulu tahu. Namun sekarang dengan perkembangan ilmu dan teknologi bukan saja penge-tahuan guru bisa sama dengan murid, bahkan murid bisa lebih dulu tahu dari gurunya. Itu semua dapat terjadi akibat perkembangan media informasi di sekitar kita sehingga pada saat ini guru bukan lagi satu-satunya sumber belajar, melainkan guru memiliki fungsi yang lebih luas yaitu sebagai penyedia fasi-litas belajar agar siswa mau belajar (fasilitator), sebagai motivator yang memberikan semangat dan energi kepada siswa untuk terus belajar. Selain itu guru harus mampu mengelola kegiatan belajar siswa, memposisikan siswa sesuai minat, potensi, dan kemampuannya dan memanfaatkan setting yang ada

(organisator) dan mampu mengevaluasi keberhasilan belajar siswa baik proses maupun hasil (evaluator). Banyak contoh, siswa dapat lebih dahulu mengak-ses informasi dari berbagai media yang ada seperti surat kabar, televisi, bah-kan internet sehingga lebih dahulu tahu dibanding gurunya. Tentu saja kondi-si ini merupakan gejala yang positif sekaligus tantangan bagi para guru untuk memperbaiki proses pembelajaranya.

Potensi-potensi yang tersebar di sekolah dan di masyarakat berupa sumber belajar harus menjadi perhatian guru untuk diorganisasi dengan baik sehingga berdayaguna positif 
untuk keberhasilan belajar siswa. Perkembangan teknologi yang ada serta perubahan kurikulum menuntut guru untuk lebih kre-atif, tidak lagi selalu menunggu instruksi dari pusat. Guru adalah tenaga profesional, sehingga harus cepat menyesuaikan diri dan mereposisi perannya. Pada saat ini guru tidak lagi harus menjadi orang yang paling tahu di kelas. Namun ia harus mampu menjadi fasilitator belajar dan pengelola sumber belajar bagi siswanya.

\section{B. KAJIAN LITERATUR}

\section{Konsep Sumber Belajar}

Sumber belajar adalah segala sesuatu yang ada di sekitar lingkungan ke-giatan belajar yang secara fungsional dapat digunakan untuk membantu opti-malisasi hasil belajar.. Konsep Edgar Dale dalam teorinya Cone Experience yang menjelaskan bahwa hasil belajar dapat diperoleh lebih optimal dengan cara melakukan sendiri atau paling tidak me-lihat objek nyata. Hal tersebut dapat dilakukan dengan melakukan kegiatan Fild Trip seperti karyawisata... Dengan demikian diperlukan kreatifitas guru untuk menjadikan pem-belajaran lebih efisien namun hasilnya lebih efektif dengan berpijak pada prinsip pengalaman belajar Edgare Dale di atas.

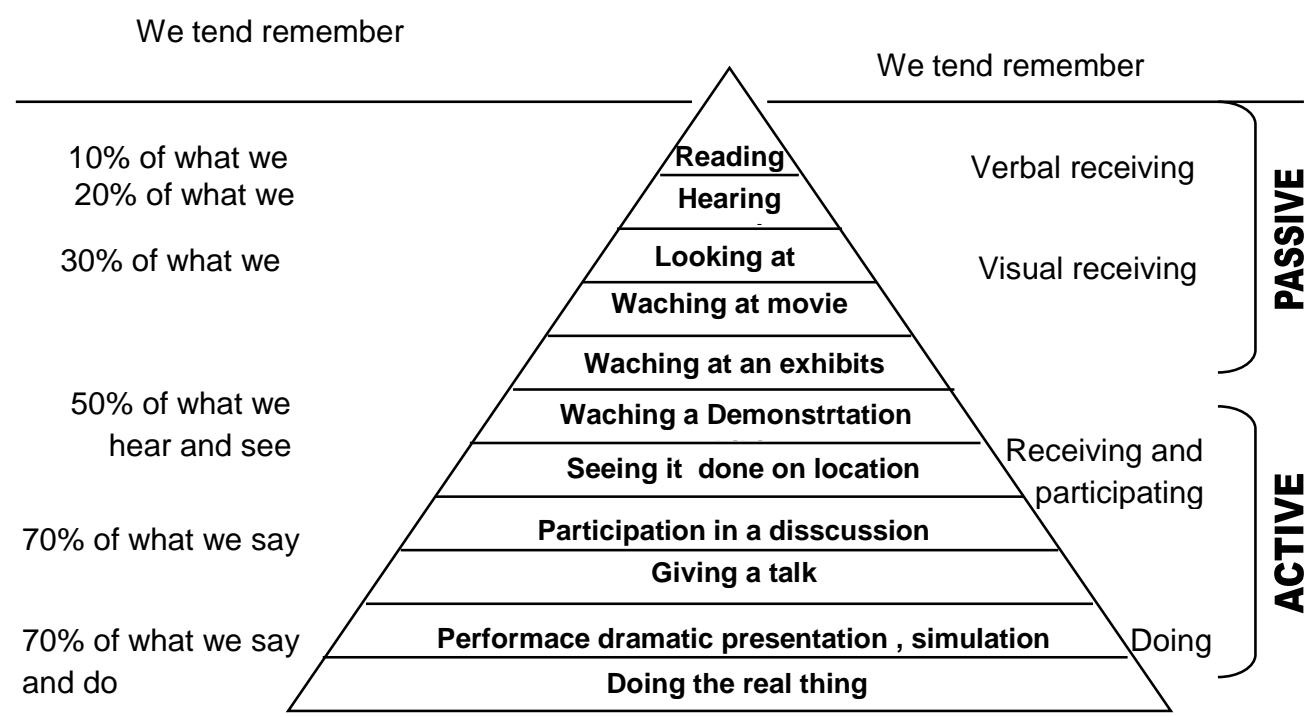

Kedua pemanfaatan sumber belajar dengan menggunakan fasilitas yang sudah terse-dia dan tidak dirancang secara khusus untuk pembelajaran namun dapat digunakan secara langsung (media by utilization).Ketiga, disebut media by design. Dalam hal ini guru merancang media sesuai dengan tuntutan tujuan materi dan karakteristik siswa, seperti gambar, foto, film, video tentang objek tersebut untuk dipergunakan di kelas. Cara ini akan sangat membantu guru dalam memberikan penjelasan.. Treatment pembelajaran seperti ini menghasilkan perolehan pengeta-huan dan pemahaman lebih dari $50 \%$ dan dapat dikatakan pembelajaran cu-kup berhasil. Seperti yang kita tahu tentang teori Cone Experience (Kerucut Pengalaman) dari Edgar Dale berikut ini: 


\section{Makna Media Pembelajaran}

Kata media berasal dari bahasa latin dan merupakan bentuk jamak dari kata medium yang secara harfiah dapat diartikan sebagai perantara atau pe-ngantar. Menurut Heinich, Molenda, dan Russel (dalam Instructional Media, 1990) diungkapkan bahwa media "is a channel of communication. Derived from the latin word for "between", the term refers "to anything that carries information between a source and a receiver. Aplikasi media pembelajaran berpijak pada kaidah ilmu komunikasi, yang antara lain "who says what in which Channels to whom in what effect"

a) Who, siapa yang menyatakan? (guru, widyaiswara, pengirim pesan).

b) What, pesan atau ide/gagasan apa yang disampaikan (dalam kegiatan pembelajaran ini berarti bahan ajar atau materi yang akan disampaikan).

c) Which Channels, dengan saluran apa, media saluran apa, media atau sarana apa, pesan itu ingin disampaikan.

d) To Whom, kepada siapa (sasaran, siswa, peserta didik)

e) What effect, dengan hasil atau dampak apa?

. Dalam kajian kependidikan, istilah itu dikenal dengan "meaningful learning experience", yaitu suatu pengalaman belajar yang bermakna sebagai hasil dari suatu kegiatan pembelajaran. Proses belajar mengajar hakikatnya adalah proses komunikasi, guru ber-peran sebagai pengantar pesan dan siswa sebagai penerima pesan. Pesan yang dikirimkan oleh guru berupa isi/ ajaran yang dituangkan ke dalam simbol-sim-bol komunikasi baik verbal (kata-kata \& tulisan) maupun nonverbal. Proses ini dinamakan encoding. Penafsiran simbol-simbol komunikasi tersebut oleh siswa dinamakan decoding. Namun bagaimanakah bentuk dan wujud dari me-dia atau perantara ini, hal tersebut harus disesuaikan dengan jenis dan karak-teristik materi yang akan disampaikan serta kemampuan guru tentang penge-tahuannya mengenai media. Metode dan alat, yang dalam hal ini adalah media pembelajaran berfungsi untuk menyampaikan mate-ri pelajaran agar sampai kepada tujuan.

\section{Hasil Belajar.}

Menurut Nana Sujana (2008:22)" Hasil belajar adalah kemampuan-kemampuan yang dimiliki siswa setelah ia menerima pengalaman belajarnya", menurut $A$. Tabrani (1989: 21)'Hasil belajar diperlukan untuk melihat sejauhmana taraf keberhasilan mengajar guru dan belajar peserta didik secara tepat(valid) dan dapat dipercaya(reliable). Menurut Ngalim Purwanto (2001:107) faktor faktor yang mempengaruhi hasil belajar itu terdiri 1) faktor luar, seperti: lingkungan sosial, instrumental/kurikulum,bahanajar,sarana, dan manajerial. 2) faktor dari dalam

\section{Pembelajaran Bahasa Indonesia}

Pembelajaran Bahasa Indonesia merupakan materi pembelajaran Pendidikan karakter dapat dimaknai sebagai pendidikan nilai, pendidikan budi pekerti, pendidikan moral, pendidikan watak yang bertujuan untuk mengembangkan kemampuan siswa agar dapat memberikan keputusan baik-buruk, memelihara apa yang baik, dan mewujudkan kebaikan itu dalam kehidupan sehari-hari dengan sepenuh hati. (Rencana Aksi Nasional Pendidikan Karakter, Kemdiknas 2010 - 2014). Secara umum ada tiga kelompok pendidikan karakter yang ingin dikembangkan, yaitu: (1) pendidikan karakter yang menumbuhkan kesadaran sebagai makhluk dan hamba Tuhan Yang Maha Esa; (2) pendidikan karakter yang terkait dengan keilmuan; dan (3) pendidikan karakter yang menumbuhkan rasa cinta dan bangga menjadi orang Indonesia. Aktualisasi nilai dalam pembentukan karakter melalui dunia pendidikan memerlukan perencanaan yang teliti dan matang agar proses dan 
hasilnya sesuai dengan yang diharapkan. Proses penanaman nilai dalam pembentukan karakter melalui pendidikan harus dikemas dengan baik dan terstruktur yang dapat diimplementasikan melalui pengembangan pembelajaran Bahasa Indonesia.

Pembentukan karakter siswa dalam pembelajaran dilakukan melalui kegiatan perencanaan, pelaksanaan, dan evaluasi pembelajaran. Karakter yang akan dibentuk hendaknya diintegrasikan ke dalam mata pelajaran Bahasa Indonesia.

Proses penanaman nilai dalam pembentukan karakter siswa tersebut di atas sejalan dengan proses pembelajaran sebagaimana yang ditegaskan dalam Peraturan Pemerintah Nomor 19 tahun 2005 Bab IV Pasal 19 ayat 1 yang menyatakan bahwa "Proses pembelajaran pada satuan pendidikan diselenggarakan secara interaktif, inspiratif, menyenangkan, menantang, memotivasi siswa untuk berpatisipasi aktif serta memberikan ruang yang cukup bagi prakarsa, kreativitas, dan kemandirian sesuai dengan bakat, minat, dan perkembangan fisik serta psikologis siswa." Hal tersebut merupakan dasar bagi pendidik untuk menyelenggarakan pembelajaran agar menjadi aktif, kreatif, efektif, dan menyenangkan (PAKEM).

\section{METODE PENELITIAN}

Penelitian ini dilakukan bagi siswa kelas VI SDN 1 Nyalindung Kecamatan Cipatat Kabupaten Bandung Barat yang merupakan sekolah dimana peneliti bertugas sebagai guru kelas pada lembaga itu. Dengan jumlah siswa sebagai responden sebanyak 20 orang siswa. Sedangkan penelitian dilaksanakan selama satu bulan, yaitu mulai tanggal 03 Oktober 2012 sampai dengan tanggal 31 Oktober 2012. Dengan rancangan penelitian dilakukan dalam tiga siklus.

\section{HASIL DAN PEMBAHASAN}

Pelaksanaan kegiatan penelitian untuk siklus I dilaksanakan pada tanggal 03 Oktober 2012 sampai dengan tanggal 08 Oktober 2012 di SD Negei 1 Nyalindung Kecamatan Cipatat Kabupaten Bandung Barat tahun ajaran 2012-2013, dengan jumlah guru 20 siswa. Dalam hal ini peneliti bertindak sebagai guru kelas adapun proses penelitian mengacu pada rencana pembelajaran menggunakan media pembelajaran yang telah dipersiapkan, dan dilaksanakan pada saat proses belajar pembelajaran.Pengamatan (observasi) dilaksanakan bersamaan dengan pelaksanaan proses belajar mengajar. Pada akhir pembinaan diberi test penilaian I dengan tujuan untuk mengetahui peningkatan hasil dari proses pembelajaran yang telah dilakukan. Adapun data hasil penelitian pada siklus I. adalah sebagai berikut :Pelaksanaan kegiatan pembinaan pada siklus I ini masih terdapat kekurangan , sehingga perlu adanya revisi untuk dilakukan pada siklus berikutnya.Guru perlu lebih terampil dalam memotivasi siswa dan lebih jelas dalam menyampaikan tujuan pembinaan. Mendistribusikan waktu secara baik dengan menambahkan informasiinformasi yang dirasa perlu dan memberikan catatan. Terampil dan bersemangat dalam memotivasi siswa sehingga mereka bisa lebih antusias.Pelaksanaan kegiatan untuk siklus II dilaksanakan pada tanggal 10 Oktober 2012 sampai dengan tanggal 15 Oktober 2012 di SDN 1 Nyalindung Kecamatan Cipatat Kabupaten Bandung Barat Tahun Pelajaran 2012 -2013. Dalam hal ini Peneliti bertindak sebagai guru kelas. Adapun proses kegiatan mengacu pada rencana kegiatan dengan memperhatikan revisi pada siklus I, sehingga kesalahan atau kekurangan pada siklus I tidak terulang lagi pada siklus II. Penelitian Tindakan Kelas ini dilaksanakan sesuai dengan porsedur rencana pembinaan dan pelaksanaan pembinaan dilaksanakan pada saat proses belajar mengajar berlangsung.Pada akhir 
proses kegiatan, siswa diberi test formatif II, dengan tujuan untuk mengetahui tingkat keberhasilan dalam proses pembelajaran.Instrument yang digunakan adalah test formatif II. Adapun data hasil penelitianDari tabel di atas dapat dijelaskan bahwa dengan pembelajaran melelui media pembelajaran diperoleh nilai rata-rata 64.75 $\%$, dan peningkatan siswa dari 20 orang siswa, baru 15 orang yang sudah tuntas ( 75 $\%$ ).Pelaksanaan kegiatan penelitian untuk siklus III dilaksanakan pada tanggal 17 Oktober 2012 sampai dengan tanggal 22 Oktober 2012 di SD Negeri 1 Nyalindung Kecamatan Cipatat Kabupaten Bandung Barat tahun ajaran 2012 -2013, dengan jumlah 20 orang siswa. Dalam hal ini peneliti bertindak sebagai Guru Kelas.Adapun proses pembelajaran mengacu pada rencana pembelajaran dengan memperhatikan revisi pada siklus II, sehingga kekurangan dan ketimpangan yang terjadi pada siklus II tidak terulang kembali pada pelaksanaan siklus III. Pengamatan (observasi) dilaksanakan bersamaan dengan proses belajar mengajar di sekolah.Pada akhir proses pembelajaran diberi test formatif III dengan tujuan untuk mengetahui tingkat keberhasilan siswa dalam dalam proses pembelajaran di kelas yang telah dilakukan. Instrument yang digunakan dalah test formatif III. Adapun data hasil penelitian pada siklus III adalah sebagai berikut :

\section{Analisis Data Deskriftif Kuantitatif}

1. Pencapaian peningkatan hasil pembelajaran sebelum kegiatan penelitian adalah $:=(1080 / 2000)$ x $100 \%=54 \%$

2. Peningkatan hasil pembelajaransetelah kegiatan penelitian adalah :

$=(1295 / 2000) \times 100 \%=$ $64.75 \%$
3. Peningkatan hasil pembelajaran setelah pelaksanaan kegiatan adalah

$=(1440 / 2000) \times 100 \%=72 \%$

Dari hasil analisis tersebut dapat disimpulkan bahwa :

a. Terjadi peningkatan hasil pembelajaran setelah diberi penguatan melalui pendekatan media pembelajaran yaitu peningkatan hsil proses pembelajaran:

b. $54 \%$ menjadi $64.75 \%$ terdapat kenaikan sebesar $=10.75 \%$

c. Dari sebelum penelitian (siklus I) dan setelah penelitian sampai dengan siklus II, $54 \%$ menjadi $64.75 \%$, dan pada siklus III, juga mengalami kenaikan yaitu sebesar : $(72 \%-64.75 \%)=$ $7.25 \%$

d. Rata-rata peningkatan hasil proses pembelajarandalam proses penelitian semula hanya $20 \%$, naik menjadi $100 \%$.

\section{Refleksi dan Temuan}

Berdasarkan pelaksanaan penelitian yang telah dilaksanakan guru kelas kepada pada siswa kelas VI SDN 1 Nyalindung Kecamatan Cipatat melalui pendekatan media pembelajaran, maka hasil observasi nilai, dapat dikatakan sebagai berikut :

a) Pertemuan pertama kegiatan penelitian belum berhasil karena dalam pelaksanaan pembelajaran masih terlihat para siswa belum begitu antusias, karena kurang begitu menarik minat dalam proses pembelajaran.

b) Pengajaran yang dilakukan melalui media pembelajaran, dalam hal peningkatan prestasi belajar siswabelum nampak, sehingga hasil yang dicapai tidak tuntas.

c) Mungkin karena proses pembelajaran melalui media pembelajaran baru mereka laksanakan, sehingga para siswa merasa kaku dalam PBM. 
d) Setelah mendapatkan penjelasan, para siswa dapat memahaminya dengan terbukti pada pertemuan berikutnya dapat berjalan lebih baik, semua siswa aktif dan lebih-lebih setelah ada rubric penilaian proses, semua siswa antusias untuk mengikutinya dan telah mencapai ketuntasan.

Peningkatan Guru dalam MengajarMelalui hasil penelitian ini menunjukan, bahwa kegiatan penelitian ini memiliki dampak positif dalam meningkatkan hasil proses pembelajaran, hal ini dapat dilihat dari semakin meningkatnya kemampuan siswa yang secara umum meningkat dari siklus I, siklus II, dan siklus III , yaitu masing-masing : $54 \% ; 64.75 \%$; dan $72 \%$ secara kelompok dikatakan tuntas / meningkat karena sudah mencapai ketuntasan.Meningkatnya kompetensi akademik siswa, yakni meningkatkan kinerja guru dalam manajemen proses pembalajaran :Berdasarkan analisis data, diperoleh aktifitas siswa dalam meningkatkan prestasi belajar di setiap siklus yang mengalami kemajuan .Aktifitas guru dalam kegiatan pembelajaran melalui pendekatan media pembelajaran semakin meningkat Berdasarkan analisis data, diperoleh aktifitas siswa yang paling dominan dalam kegiatan penelitian adalah proses pembelajaran dengan menggunakan alat / media, mendengarkan / memperhatikan penjelasan guru kelas, dan diskusi antar siswa dengan teman sejawatnya yakni dalam kegiatan tugas proses pembelajaran . Jadi dapat dikatakan bahwa aktifitas siswa dapat dikatagorikan aktif progressif, yang menunjukan bahwa aktivitas dan peningkatan hasil proses pembelajaran cukup meningkat. Hal ini terlihat pada pertemuan dengan 20 siswa yang ada saat penelitian ini dilakukan, dengan mencapai nilai rata-rata yakni $54 \%$ meningkat menjadi $64.75 \%$ pada siklus II, juga pada siklus III meningkat menjadi 72
\%. Dari ananlisis data tersebut, dapat dikatakan bahwa kegiatan penelitian yang dilakukan penulis efektif untuk dapat diterapkan dalam upaya meningkatkan prestasi hasil proses pembelajaran, yang berarti proses pembelajaran melalui media pembelajarn lebih berhasil dan juga berdampak positif dalam rangka meningkatkan dan memotivasi kreatifitas dan spirit para siswa di kelasnya. Untuk hal inilah mudah -mudahan pendekatan ini juga dapat digunakan sebagai media dan tekhnik pembelajaran. Dari ketercapaian peningkatan prestasi hasil belajar para siswa dalam rangka pelaksanaan proses kegiatan belajar mengajar, juga dapat mencerminkan budaya kekeluargaan dan partisipasi aktif selama kegiatan berlangsung, dan juga pendekatan ini pula merupakan kewajiban guru kelas dalam rangka pelaksanaan tugas pokok dan fungsinya di lapangan pekerjaannya. Dengan kata lain pendekatan pengelolaan manajemen kelas sangat efektif dilaksanakan dan berdampak positif dalam rangka meningkatkan kompetensi para pelaksana pendidikan atau tenaga pendidik.

\section{E. SIMPULAN DAN REKOMENDASI}

Berdasarkan analisis hasil penelitian dan diskusi, dapat disimpulkan sebagai berikut :

1) Pembinaan pengawas dalam upaya meningkatkan kinerja guru dalam manajemen pengelolaan kelas melalui penerapan supervisi klinis menunjukan peningkatan pada setiap putaran (siklus)

2) Aktifitas dalam kegiatan pembinaan menunjukan bahwa seluruh guru dapat meningkatkan kinerjanya dengan baik di setiap aspek.

3) Peningkatan mutu sekolah oleh pengawas melalui supervise klinis ini menunjukan peningkatan dari setiap siklusnya.

4) Aktivitas para guru menunjukan bahwa kegiatan pembinaan melalui penerapan supervise klinis bermanfaat dan dapat membantu para guru untuk 
lebih mudah memahami konsep, peran, dan fungsi guru. Sehingga peningkatan kinerja para guru dalam mengajar di kelasnya berjalan dengan harmonis dan menciptakan suasana proses pembelajaran yang aktif, kreatif, dan menyenangkan.

Berdasarkan hasil penelitian dan pembahasan serta simpulan-simpulan yang diperoleh maka berikut adalah rekomendasi yang dapat ditujukan kepada sejumlah pihak, yaitu sebagai berikut:

1) Penelitian perlu dilanjutkan dengan serangkaian penelitian yang mengembangkan alat ukur keberhasilan yang lebih reliable, agar dapat menggambarkan peningkatan kinerja guru dalam mengajar di kelas secara efektif dan efisien dalam mencapai mutu pendidikan.

2) Pembinaan pengawas melalui penerapan supervisi klinis diperlukan perhatian yang penuh dan disiplin yang tinggi pada setiap langkah pembinaan, dan perencanaan yang matang, misalnya dalam pengalokasian waktu dan pemilihan konsep yang sesuai.

3) Kepada para guru diharapkan untuk selalu mengikuti perkembangan technology, terutama dengan sering membaca karya para akhli, memonitor perkembangan dunia pendidikan melalui media massa dan elektronika untuk menghindari ketimpangan dan ketinggalan informasi teruama dalam perkembangan pendidikan di Indonesia Khususnya umumnya dunia pendidikan secara keseluruhan.

\section{F. REFERENSI}

Adey, P. 1989. Adolescent development and school science.International Journal of Science Education, 79: 98. England.
Alessi M. Stephen \& S.R., Trollip. 1984. Computer Based Instruction Method \& Development. New Jersey: PrenticeHall, Inc.

Barbara B. Seels, Rita C. Richey. 1994. Instructional Technology: The Definition and Domains of The Field, AECT Washington DC.

Bates, A. W. 1995.Technology, Open Learning and Distance Education.London: Routledge.

Cepi Riyana. 2004. Strategi implementation Teknologi Informasi dan Komunikasi dengan Me-nerapkan Konsep Instructional Technology. Jurnal Edutech, Jurusan Kurtek Bandung.

Cepi Riyana. 2006. Media Pembelajaran. Modul, Fakultas Ilmu Pendidikan.

Depdikbud. 1993. Kurikulum SD 1994. Jakarta: Depdikbud.

Drive, R. $\quad 1988$ Changing conceptions.Journal of Research in Education, 161-96.

Gerlach, S. Vernon. 1980. Teaching and Media. New Jersey: Prentice-Hall., Inc.

Heinich, R., Molenda, M., \& Russel, J.D. 1996. $\quad\left(3^{\text {rd }} \quad\right.$ Ed).Instructional Technology for Teaching and Learning: Designing Instruction, Integrating Computers and Using Media. Upper Saddle River, NJ.: Merril Prentice Hall.

Kemp, Jerrold E. 1994. Designing Effective Instruction. New York: MacMillan Publisher.

Kenji Kitao. 1998. Internet Resources: ELT, Linguistics, and Communication. Japan: Eichosha.

Molenda, Heinich Russell. 1982. Instructional Media and The New Technology of Instruction. Canada: John Wiley \& Son.

Sadiman Arief. 1990. Media Pendidikan, Pengertian Pengembangan dan Pemanhattan. Jakarta: Rajawali. 